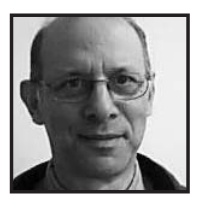

\title{
Using a Theatre as Representation Scenario as a Teaching Vehicle in B.Ed and M.Ed Preparation Programs
}

\author{
Matthew J. Meyer, St. Francis Xavier University
}

\section{ABSTRACT}

The following article demonstrates the use of the dramatic scenario, The Insurrection (a TAR/ethno-drama fiction work) to teach fundamental educational administration concepts to graduate and preservice teacher candidates. The scenario was written specifically to address the conflicts related to communication within a secondary school community and is used as a provocation tool in classroom discussions.

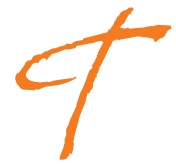

heatre as Representation (TAR) is a teaching pedagogy that utilizes a dramatic scenario to provoke discussion and decision-making possibilities within a preservice classroom management curriculum and/or a graduate leadership curriculum (Meyer, 1998, 2001, 2003, 2004, 2005). The scenario itself is inspired either by research interviews on a specific subject or, as, in this scenario, an actual event. The scenario's purpose is to bring to light to specific issues of leadership and decision making that can affect-positively or negatively - the values and ethics of school life such as school culture, climate, accountability, and inter-constituency communication.

\section{Background}

While I was doing my graduate work with the late Geoffrey Isherwood of McGill University in the mid 1990's, I realized that much leadership theory was still 
existing within the positivistic paradigm as espoused by the followers of Simon (1945/1976), Merton (1967), and Griffiths (1988), to name a few. One opposing view to this came from the late Tom Greenfield (1993), who advocated a more responsive vision of leadership where ideas, power, and control of leaders were more open to collegial and co-operative activities and interactions. In the late 1960s and early 1970s, these theoretical deliberations were mostly known as the "Greenfield/Griffiths" debates within the leadership field. As a graduate student in educational administration, I was hearing mixed messages where on one hand, the school boards were instructing their future administrators in the traditional transactional leadership style of "this is the way we do it around here" preparation programs. On the other hand, as graduate students, we were informed about transformational (precursor to distributive) leadership. With this information in hand I toyed with the idea that school administrator preparation programs required some sort of alternative simulation-like activities rather than the typical "in/out basket" exercises.

Because I had a phenomenological stance in theatre education I began to experiment with the interview data I was collecting for my thesis. Along with typical coding, and reducing data into themes and subsets of conclusions, I began to create scenarios that would depict the issues that these subsets of information inspired. This technique of data-driven scenarios became Theatre as Representation (TAR) (see Meyer, 1998 for more details). Starting in 1993 from the very first public presentations at the Canadian Association for Study of Educational Administration Annual Meeting in Ottawa, and in educational administration graduate classes and conferences, the success of these scenarios was very encouraging. TAR would also fall into the more recent qualitative research approach called ethnodrama (see Saldaña, 2005).

\section{TAR as a Teaching/Learning Style}

From a teaching/learning perspective, theatre as representation, or ethnodrama-inspired scenarios, are employed in teacher and administrator preparation programs in what could be best described as a fused combination of learning-bydoing construction (Dewey, 1934) within a constructivist framework (Vygotsky, 1978). TAR is Dewey-like in the sense that participants become partially embedded in the characters' personas and then step out of those personas to either discuss or rework those personas in a hands-on manner. It is constructivist in the sense that the sequential and actual participant involvement in and subsequent deconstruction of their assumed personas leads to a deeper analysis of their characters. This design then 
creates discussion formats and alternative conflict resolution possibilities for the scenario. The TAR scenario process also can produce discussions and strategies for reallife leadership decision-making issues.

In this application, TAR is founded on two rudimentary constructions and a third supporting one (Meyer, 2004). The first construction is based on traditional drama, theatre, and production practices as passed down through generations of performance practice, along with concepts espoused by such theorists as Beckerman (1970), Bolton (1979), Brecht (1948/1964), and Warren (2002), to name a few.

The second foundational view comes from a fusion of social constructivist learning theories: Fosnot (1996), Goleman's $(1995,1998)$ notion of emotional intelligence, and Hutchins' (1995) thoughts of cognition. When a TAR scenario is used within a teaching pedagogy, all students have the opportunity to take on character roles in the piece (either as actors or readers) and to be audience members. Each TAR scenario incorporates fundamental aspects of administrative and organizational theory (e.g., sources and uses of power, micro-politics, etc.) fleshed out through the use of research and/or analysis of extensive interviews with in-service practitioners. This would hold up to work by McCammon, Norris, and Miller (1998) where, "the goal of most teacher education preparation programs is the development of reflective teachers who can examine and re-examine their knowledge, beliefs and values about teaching and learning" (p. 1). If so desired, the actual interview data that inspired the TAR scenario, after appropriate editing, can initiate discussions among participants regarding a specified topic.

The third supporting concept comes from a synthesis of educational leadership, power, and drama (theatre) relationship ideas regarding power. The former is mostly predisposed by Hodgkinson's $(1983,1991)$ theories of value leadership, ethics in leadership (Shapiro \& Stefkovich, 2005), theories in transformational leadership (Burns, 1978; Sergiovanni, 1990), Leithwood's (1999) ideas on decentralizing, constructions of distributed leadership (Spillane, 2006) and the design of future schools. The latter is devised from notions of Brecht's alienation theory (1964/1974), Boal's political theatre concepts, and to a lesser degree, some drama education theory on performance (Boal, 1985), group creation and structures (Jackson, 1993; O'Neill \& Lambert, 1982) and drama group dynamics and story telling (Booth, 1994; Neelands \& Goode, 2000). 
This classroom collaborative activity is highly different than a standard case study exercise. Typically, case studies are somewhat technical, descriptive and linear deconstructions of incidents (designed or actual) that have an expected outcome. Cases are frequently based on actual incidents or litigation. Usually written in the past tense, a case study gives facts, actions, and probable conclusions. Theatre as Representation contains many of these elements; however, the distinguishing feature in TAR is its live presentation. Facts come alive with actual live voices. Character participants can emotively and psychologically empathize directly with the characters they are portraying. Students not involved it the dramatization serve as an audience to watch and weigh the merits of the case as it is portrayed.

Theatre as representation scenarios are inspired by real events; however, they are not the real event itself. There is some artistic license in both their creation and in their presentations. Herein lies the advantage of using this approach in a B.Ed or M.Ed learning environment. The live participation of all participants (active or passive) is altered each time a different participant takes on a specific role. Whether it is how a word or phrase is spoken, modulated, or creatively positioned within the scripted dialogue, participants can spontaneously modify characteristics as they are representing them. This spontaneity provokes directional, interpretative alterations to preconceived traits of the portrayed characters.

There have been other qualitative research-inspired scenario constructions that are used in preservice and related instruction. Of note are Jim Mienczakowski's (1996) work in health education and George Belliveau's (2006) research in social justice and teacher education. TAR scenarios differ from these examples. TAR scenarios are scripted based on interviews, or observed instances, or from stories. They are not inspired from a classroom group collective exercise or improvisation protocol.

The pedagogical foundation of TAR is to have students explore the possibilities for further direction and content of a scenario. The discussions that typically follow a class presentation usually deal with a number of related issues about the content or facts of the scenario. A TAR scenario triggers, or even goads, participants into taking sides about the content or portrayed personalities. It initiates many "what if?" questions and reflective inquiries, both into the content and the characters.

The following case, is one of dysfunctional communication, school governance, and school leadership. For the purposes of this short presentation, it serves as a classroom discussion provocation piece. In its typical classroom application, the instructor arbitrarily distributes the parts and in a readers' theatre-like setting, the 
piece is read out loud. It is not important to have male and female participants reading corresponding parts. Most TAR scenarios are based on actual incidents. The inspired characters are based on actual personalities. Following the reading, the discussion question posed to the class is, "What just happened here?"

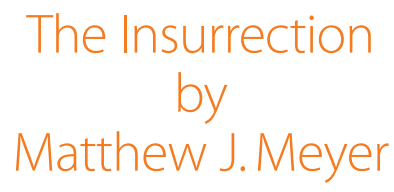

It is early December, on the Monday following the annual "semi-formal" school cotillion. The school principal is having an emergency meeting with several members of the parents' executive committee of the senior boys'basketball team. The team coach has quit because four of the grade 12 team members decided to attend the cotillion against his ruling, which conflicted with the date of an invitational basketball tournament.

This is based on a true incident; however, not all events occurred as indicated in the text. Actual names have been changed.

Characters:

Mr. Pruit, School Principal, Mrs. Betty Miller, Mr. Greg Dogwood, Mr. Norbert, Mrs. Guyot

Mrs. Miller: Mr. Pruit, you must do something about this situation. Our basketball coach Paul Katz has given our high school four years of his valuable volunteer time in coaching our children. You must support him in this situation. His authority as Coach is in jeopardy. How can you overstep his mandate?

Mr. Pruit: $\quad$ First of all Mrs. Miller, let me remind you that as Principal, I have the authority and mandate to govern this school according to both the Provincial Education Act and our School Board protocols. That includes all academic and extracurricular activities. So please permit me to do my job! 
Mrs. Miller: Yes we know that, you have told us that many times. But it was you who first begged Coach Katz to take over the team in the first place...

Mr. Dogwood: Betty, will you let him explain all the facts before you chop his head off? You're not letting him speak.

Mr. Norbert: Greg, if it were not for your son and his buddies we would not be in this mess to begin with. Betty is right. The Coach has been undermined and now we don't have a coach ...

Mr. Dogwood: That's entirely unfair. My son and the others did nothing wrong and you should not be blaming his quitting on them.

Mr. Norbert: They went behind the Coach's back. They knew that their absence from the tournament meant that the team had no chance of doing well. The team must come first. That's loyalty.

Mr. Dogwood: The boys were willing to take punishment and such but to be permanently suspended?? That's too, too much!

Mrs. Miller: And now we have no Coach and now-no team!

Mr. Pruit: $\quad$ Stop this bickering. We still have a team ... just no coach at the moment. So please everyone calm down. These are the facts as I have pieced them together. I have spoken to Paul, the boys in question, the Assistant Coach Tom, and most of you. Let me speak without interruption please. Before any of this came to me, here's what happened. Back in late August, Paul made the game schedule with all the other regional coaches. He had been given our complete school calendar of events. As Coach, he informed the team members that missing a game or being late for a practice would bring some sort of negative consequence to them and to the team. I do not interfere with the way coaches run their teams, so I am not aware of those consequences. But having been a coach myself for many years I have a pretty good idea. Next, a month ago at a parent meeting, Mrs. Dogwood asked the Coach what would the reprisals be for any team 
member who missed the November $26^{\text {th }}$ Tri-County Invitational Tournament. That weekend tournament happened to be in conflict with our school's annual SemiFormal Cotillion Dance. Paul said he would think about such consequences and inform the parents. Two weeks passed. Paul sent a letter to all the parents informing them that he felt the team members' first obligation was always to the team and that a school dance was secondary to that commitment. He stated that the consequences for missing that tournament would be severe. But he did not specifically state what they would be. He also indicated that this was an invitational tournament and that even though the results would not affect the teams' standings, the experience would be tremendous in aiding in the team's growth as they moved towards the regional playoffs.

Mr. Norbert: Yes, Yes we know all that ...

Mrs. Guyot: Let him finish!

Mr. Pruit: $\quad$ Next. At the beginning of last week, four days before the tournament, Paul left the practice early to catch a plane for a business engagement out of town. He was to return the day before the tournament to hold a practice. However, he still didn't inform the team of the possible consequences. Within that time, the four senior boys who wanted to go to the dance went to Tom to ask what to do. Tom suggested they come to me since Paul was out of town. I informed the boys that they would not be penalized for attending the dance since this event is a major school event and that it was my belief that no graduating senior should miss the opportunity of attending it.

Mrs. Miller: So you gave them permission to miss the tournament. That's outrageous. No wonder Paul quit-you destroyed his credibility!

Mr. Pruit: $\quad$ (annoyed at being again interrupted) Paul was away and I could not contact him. Upon his return, last Wednesday, he 
went directly to the practice but found that he could not hold the practice because the gym was being transformed into a ballroom. Because the practice had to be cancelled, most of the players had left but a few were milling around the gym. Paul was angry that he could not hold the practice because the tournament was the following day. One of the junior team members asked him who the starting five players were going to be since the four seniors would be absent. Paul exploded in a rage saying no one had informed him that these four would not be at the tournament and then he stormed into my office.

Mr. Norbert: Well, wouldn't you do the same? How come you did not inform him of the cancelled practice in advance or leave him a phone message about your decision on "no reprisals?"

Mr. Pruit: $\quad$ As I was saying ... Paul came into my office fuming. I attempted to calm him down and I explained my decision, which he did not accept. He said bluntly that I, even as Principal, had no right to interfere with the running of the team and that if I could not accept that, he would stop being coach. I would not change my decision, so he quit right then and there.

Mrs. Miller: You were so unfair to him and to our children by siding with those four. Their personal social needs for attending that dumb dance have put the entire team in jeopardy. Paul is a great coach and now our children feel deserted. That is entirely unacceptable.

Mrs. Guyot: I take great offence at your insinuation that my son and the other three boys are disloyal. They have been on the team since grade 10 , have never missed a game or practice, and have given up weekends, a social life, and a lot more. And how about us as parents, we have supported this team for years driving them everywhere, providing food and bottle drives, and hosting tournaments. Your son is only in Grade 10 , don't talk to me about loyalty! 
Mr. Pruit: Paul's final word was that due to my "overriding" his punishment protocols, in this case permanent suspension, he felt that his authority was compromised. I informed him that I disagreed. Our school policy regarding conflicts between school events is flexible. However, the dance had been on the calendar since last spring, and in my view he should have taken that into account prior to making commitments. Further, this tournament was an invitational one and its results would not affect the team's standings.

Mrs. Miller: All that is irrelevant. Whether or not the tournament counts is not the important thing. What is important is that the team members understand their responsibility when they tried out for and made the team. There is no sense of honour.

Mrs. Guyot: This is high school basketball, not a military obligation. They are kids, not dogs in an obedience school. Let's not get carried away here. Paul was too serious. We are talking about an important school event for our kids. And this was an invitational tournament. He could have played the bench players and give them some needed experience. We even would have driven them to the tournament the next day. In that way they would only have missed one actual game. He knew that. I support Mr. Pruit here.

Mr. Norbert: That's because it's your son who has caused this disaster! If it weren't for his decision and that of the other three Paul would still be coach! Those kids went around the coach's back. They didn't have the gumption to face the coach directly ... such cowards.

Mrs. Guyot: You are truly an ass, Norbert. The coach wasn't around first of all and they went through the assistant coach and Tom brought the matter to the Principal. They went through the only channel they could-especially since Paul did not respond to our request to define the sanctions. And don't call my son a coward. 
Mrs. Miller: The point here is that we want Paul back as coach and these four students punished, Mr. Pruit. You owe that to the team.

Mr.Dogwood: No he does not. Paul quit because he disagreed with the Principal's decision. The Principal runs the school. He made a judgment call and that's that. The only thing left to do here is for the Principal to hire a new coach.

Mr. Pruit: Ladies and gentlemen. Please calm down. My decision stands firm regarding sanctions. I will speak to Paul and see if an arrangement can be reached. I highly doubt it. I will find another coach. That is my responsibility.

Mr. Norbert: If Paul is not the coach, then I'm taking my boy off the team.

Mrs. Miller: Mine too. Mr. Pruit, there are eight other parents who will do the same and this is mid-season. There would be no team.

Mr. Pruit: I do not respond well to threats. All we need to field are five or six players; and there are that many left. I am sure we can have a tryout fairly soon to make up the squad's membership. There will be a team and a coach even if it's me! When all these items are addressed, I will e-mail or telephone all of you within the next few days.

\section{Classroom Discussion Possibilities}

Decision making is an ongoing responsibility and task of all school administrators. Within many decisions there is a moral and ethical dilemma where a position will be either challenged or supported. This is the case in this scenario where Mr. Pruit, the principal, believes that the four students who have chosen to attend the dance have priority over the coach's decision, or need, to have total control over his team. There are several issues that this scenario brings to mind. First, but not in any specific order, is which constituency believes it has the actual power and control over an extracurricular activity where a volunteer has been solicited to be responsible for, in this case, the boys senior basketball team. Second, is whether the mandate of the Principal should extend over all activities within the school, and if so, whether it has 
been explained thoroughly to all members of the constituencies involved. Third, is whether the incident has divided the parent support group and what the ramifications are for school governance, lines of communication, and the public relations between the principal, parent constituency, school board, and the general school community. Fourth, there are moral and value challenges in maintaining a healthy school culture and school climate for all students. Fifth, is whether responsibility and accountability have been designated and appraised in all extracurricular activities, especially where there are active parent support groups.

The responses to these issues from the classroom members may provide some insight into the decision-making dilemmas that an administrator must work through. Such responses can be constructed along pedagogical, leadership, and political lines. Students, either individually or in groups, can construct resolution solutions or role-play the possible dialogues between the conflicting constituent groups.

As a pedagogical teaching/learning strategy, a TAR scenario provides a provocation scheme to engage preservice and graduate education students in the moral and ethical issues of the field. As a pedagogical tool, it further fuses research, theory, and practice. If the classroom instructor has created the scenario, then he or she can choose to share the original data with the students to address trustworthiness/validity issues. A discussion of applicable theory (as in this case, leadership) can be infused into the scenario's classroom use. As a creative interaction device, the participation of the students in the scenario permits them to be characters persona and react in such ways that provoke discussion and possible alternative resolutions to the issues presented in a non-threatening ways. Participants are not judged on their acting abilities. They are reading from, not memorizing scripts. The focus is more on the content than on its dramatic presentation in a theatrical sense. The experience also provides an enjoyable and expressive communication medium for all those involved. 


\section{References}

Beckerman, B. (1970). Dynamics of drama: Theory and method of analysis. New York: Alfred A. Knopf.

Belliveau, G. (2006). Engaging in drama: Using arts-based research to explore a social justice project in teacher education. International Journal of Education \& the Arts, 7(5). Retrieved April 22, 2008, from http://www.ijea.org/v7n5/index.html

Boal, A. (1985). Theater of the oppressed. New York:Theater Communications Group.

Bolton, G. (1979). Toward a theory of drama in education. London: Longman.

Booth, David (1994). Story Drama: Reading, writing and roleplaying across the curriculum. Markham, ON: Pembroke Publishing.

Brecht, B. (1964). A short organum for the theater. In J. Willett (Ed. \& Trans.). Brecht on Theater: The development of the aesthetic. New York: Hill \& Wang. (Original work published in 1948).

Burns, J. (1978). Leadership. New York: Harper.

Dewey, J. (1934). Art as experience. New York: Perigee Books.

Fosnot, C. (Ed.). (1996). Constructivism: Theory, perspectives, and practice. New York: Teachers College Press.

Goleman, D. (1995). Emotional intelligence. New York: Bantam Books.

Goleman, D. (1998). Working with emotional intelligence. New York: Bantam.

Greenfield, T., \& Ribbins (Eds.). (1993). Greenfield on educational administration: Towards a humane science. London: Routledge.

Griffiths, D. E. (1988). Intellectual turmoil in educational administration. Educational Administration Quarterly, 15(3), 43-65.

Hodgkinson, C. (1991). Educational Leadership: The moral art. Albany, NY: SUNY Press.

Hodgkinson, C. (1983). The philosophy of leadership. Oxford, England: Basil Blackwell.

Hutchins, E. (1995). Cognition in the wild. Boston: Massachusetts Institute of Technology.
Jackson, T. (Ed.). (1993). Learning through theatre: New perspectives on theatre in education. London: Routledge.

Leithwood, K. (1999). An organizational perspective on values for leaders of future schools. In P. Begley (Ed.), Values and educational leadership (pp. 25-50). Albany, NY: SUNY Press.

McCammon, L., Norris, J., \& Miller, C. (1998). Cacophony and fugue: Pre-service narratives in drama education [Electronic version]. Research in Drama Education, 3, 29-44.

Merton, R. (1967). On theoretical sociology: Five essays old and new. New York: Free Press.

Meyer, M. J. (1998). Transitional wars: A study of power, control, and conflict in executive succession - Theatre as Representation. Unpublished doctoral dissertation, McGill University, Montreal, Quebec.

Meyer, M. J. (2001). Reflective leadership training in practice using theatre as representation. Journal of International Leadership in Education: Theory and Practice, 4(2), 147-169.

Meyer, M. J. (2004). Theatre as Representation (TAR) in the teaching of teacher and administrator preparation programs. International Electronic Journal for Leadership in Learning, 8(6). Retrieved from http://www.ucalgary.ca/ iejll

Meyer, M. J., \& Kerry-Moran, K. J. (2005). Evidence and artistic integrity in arts-based research:

The place of artistic quality. Arts \& Learning Journal, 21(1), 37-62.

Meyer, M. J., \& Macmillan, R. (2003). Enlivening data: Using theatre to communicate educational research. Arts and Research Journal, 19(1), 55-73.

Mienczakowski, J. (1996). An ethnographic act: The construction of consensual theatre. In C. Ellis \& A. Bochner (Eds.), Composing ethnography: Alternative qualitative writing. Walnut Creek: Sage. 
Neelands. J. \& Goode, T. (1999/2000). Structuring drama work: $A$ handbook of available forms in theatre and drama. London: Cambridge University Press.

O'Neill, C., \& Lambert, A. (1982). Drama structures: A practical handbook for teachers. Portsmouth, $\mathrm{NH}$ : Heinemann.

Saldaña, J. (Ed.). (2005). Ethnodrama: An anthology of reality theatre. Walnut Creek, CA: Almira.

Sergiovanni. T. (1992). Value-Added Leadership: How to get extraordinary performance in schools. Orlando, FL: Harcourt Brace.

Shapiro, J., \& Stefkovich, J. (2005). Ethical leadership and decision making in education, $2^{\text {nd }}$ edition. Mahwah, NJ: Lawrence Erlbaum.
Simon, H. (1945/1976). Administrative behavior: A study of decision-making processes in administrative organization. New York: Free Press.

Spillane, J. (2006). Distributed leadership. San Francisco: Jossey-Bass.

Warren, B. (2002). Creating theatre in your classroom and community ( $2^{\text {nd }}$ ed). North York, ON: Captus University Press.

Vygotsky, L. (1978). Mind in Society: The development of higher psychological processes. Cambridge, MA: Harvard University Press.

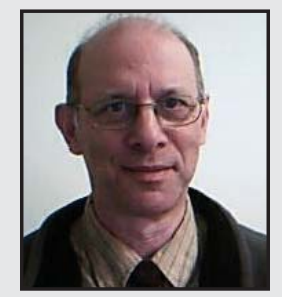

Matthew J. Meyer is an Associate Professor in the School of Education at St. Francis Xavier University, Antigonish, Nova Scotia, Canada. He teaches B.Ed and M.Ed courses in educational administration and drama-theatre educational practices. His research interests are in two distinct areas: leadership and organization aspects of school principal succession; and arts based research projects that focus on drama-theatre practices in the classroom and teacher-administrator professional development. He completed his doctoral work at McGill University.

LINKTO:

www.stfx.ca/academic/education/faculty_profiles/matthew_meyer.htm 